ART

\title{
IMAGES-METAPHORS IN THE ORNAMENTATION OF UKRAINIAN ICONOSTASIS OF THE BAROQUE PERIOD
}

Olianina Svitlana, Ph.D. in Architecture, Associate Professor of Graphic Arts Department

Publishing and Printing Institute

NTUU «Kyiv Polytechnic Institute», Ukraine

DOI: https://doi.org/ 10.31435/rsglobal_ws/30122018/6276

\section{ARTICLE INFO}

Received: 23 September 2018

Accepted: 25 December 2018

Published: 30 December 2018

\section{KEYWORDS}

Iconostasis,

donator,

coat of arms,

symbol,

meaning

\begin{abstract}
In this paper, I adduce new evidence that the decorative program of Ukrainian iconostasis contained the images-metaphors and one of them was a coat of arms of the donor. The iconoraphic programme of the Ukrainian iconostasis, during the 17th - 18th centuries is regularly complemented by coats of arms of Hetmans, Cossack leaders and highranking Orthodox clergy. These images are placed in the antependium of iconostases, usually there are several coats of arms and they belong to different family members. Accommodation of the groups of coats of arms in the iconostasis, not just the coat of arms of the donor, indicates that that was the plan that can be understood only in semantic programme of iconostasis. In the system of iconic (portrait) images of the iconostasis, the coats of arms is understood as a kind of codes, that were associated to a specific person, becoming not only his distinctive sign or sign with legal meaning, but the symbol, denoting the person and functioning as his portrait. In this sense emblems formally did not conflict with other personal images in the iconostasis and could be included in its symbolical space. At the same time, by virtue of its form of emblem, the coat of arms did not become on a par with icons, so even though it was placed in the iconostasis, it was expelled from the circle of images intended for worship. In the location of coat of arms in the iconostasis can be seen soteriological expectations of the customer and his family.
\end{abstract}

Citation: Olianina Svitlana. (2018) Images-Metaphors in the Ornamentation of Ukrainian Iconostasis of the Baroque Period. World Science. 12(40), Vol.2. doi: 10.31435/rsglobal_ws/30122018/6276

Copyright: (C) 2018 Olianina Svitlana. This is an open-access article distributed under the terms of the Creative Commons Attribution License (CC BY). The use, distribution or reproduction in other forums is permitted, provided the original author(s) or licensor are credited and that the original publication in this journal is cited, in accordance with accepted academic practice. No use, distribution or reproduction is permitted which does not comply with these terms.

Medieval Latin tradition to introduce the coats of arms of donors in decorations of the church, from the $17^{\text {th }}$ century spreads among the Orthodox in Polish-Lithuanian Commonwealth. From the second quarter of $17^{\text {th }}$ century the coats of arms of donors already were integrated in the Ukrainian iconostases. This practice it seems quite unusual, even inappropriate, because the iconostasis is the most important liturgical object in the interior of the church. This wall of icons placed on the verge of the Holy of Holies, symbolically separated the heavenly and the earthly spaces. The symbolical structure of iconostasis arose from the iconographic program of byzantine templon, which evolved in Rus' at the late $14^{\text {th }}$ - early $15^{\text {th }}$ centuries ${ }^{1}$. The general iconography and structure of iconostasis were

\footnotetext{
${ }^{1}$ Ikonostasis 2000
} 
fixed by tradition, but at the $17^{\text {th }}$ and $18^{\text {th }}$ centuries this well-established system of images in the Ukrainian iconostases was supplemented by the coats of arms of donors.

First attempt to explain the meaning of the emblems in the iconostases of Ukraine had appeared in the second decade of the $19^{\text {th }}$ century. In that time was suggested hypothesis, that emblem of donor in the iconostasis, as well as on other religious objects, is evidence of his vainglory and desire of worldly fame ${ }^{1}$. Such point of view remains relevant in the early $20^{\text {th }}$ century $^{2}$. In the studies of Soviet period dominated the idea of about realistic character of Ukranian religious art of Baroque and strong secular influence ${ }^{3}$. This long established stereotype defined the attitude to the coat of arms in the iconostasis as an evidence of overall tendency to secularization of religious art of Baroque period. In my opinion, this traditional interpretation is quite simplified. This explanation is ignoring the symbolic content of the iconostasis, which by the definition of the Orthodox theologians, is the image of the Kingdom of Heaven and the divine economy, where iconography corresponds to the liturgical prayer before the epiclesis ${ }^{4}$. No evidence that in religious consciousness of Ukrainians in $17^{\text {th }}-18^{\text {th }}$ centuries, the perception of the symbolic meaning of iconostasis was different. Byzantine basis of the iconographic program of Ukrainian iconostasis was preserved during that period. Furthermore, the devotion to the Byzantine canons was not only tradition, but also a main ideological basis of the Orthodox Church in Ukraine ${ }^{5}$. It leads one to assume that might exist others signification the coat of arms in the iconostasis, considering its role the main liturgical object in the interior of the church.

I will argue that emblems of donors in the iconostases have got more widely circle of signification. The reconstruction of the meaning of coats of arms in context of symbolic structure of the iconostasis will be aim of the present paper.

To begin with let us examine the chronology of introducing the donor emblems in the iconostasis and their location in it. The earliest example of placing the coats of arms in the iconostasis was connected with the name of Metropolitan of Kiev and Halych and All Rus' Peter Mogila. In the lower tier of the iconostasis of Saint Sophia cathedral in Kyiv, which had been created at the late 1630s and early 1640s years ${ }^{6}$, were situated two stucco emblems of Metropolitan. Their fragments were found during archaeological excavations in 1940 in the altar of the cathedral ${ }^{7}$. The following example dated from 1643. It was the iconostasis from the Annunciation church in Supraśl, where in the Apostles tier were placed the escutcheons of the Chodkiewicz family and the archimandrite Nikodem Szybiński ${ }^{8}$.

It is not possible to say that this practice had been widespread in the first half of $17^{\text {th }}$ century, because other examples unknown. But in the second half of $17^{\text {th }}$ - first half of $18^{\text {th }}$ centuries there are many such instances. Most of them are connected with the area of Left-bank Ukraine (Cossack Hetmanate). Many of hetmans and cossack leaders, who gave donations for creation of iconostases, have included into them own emblems. For example, two coats of arms of hetman Ivan Mazepa were placed in the lower tier of the iconostasis in the church of the Theotokos of the Trinity Monastery in Chernihiv ${ }^{9}$. His coat of arms was in the iconostasis (1692) in the church of the Intercession of the Holy Virgin in village Mokhnatyn ${ }^{10}$, Chernihiv region (at another source is defined as the coat of arms of hetman Ivan Skoropadsky) ${ }^{11}$. According to the written sources, in the iconostasis of the St. Catherine church in Chernihiv, which had been created about 1715 by cossack family Lizogub, in the lower tier were situated their carved coats of arms ${ }^{12}$.

Up to the present time has by chance been kept four coats of arms of cossack family Apostol in the iconostasis (1732) of the Transfiguration church in the village Velyki Sorochyntsi, Poltava region. Two of them belong to hetman Danylo Apostol, two others - to his son, cossack colonel Pavlo Apostol. About

\footnotetext{
${ }^{1}$ Berlinski 1820, pp. 98, 99.

2 Pavlutski 1910, pp. 395, 396; Modzalevski, Savitski 1992, p. 111.

${ }^{3}$ Beletski 1981, p. 66; Stepovyk 1982, p. 66-98.

${ }^{4}$ Florenski 1995, pp. 61, 62; Uspenski 1997, pp. 326, 327.

${ }^{5}$ Zholtovski 1983, p. 9-12.

${ }^{6}$ Nykytenko 2007, p. 24.

${ }^{7}$ Karger 1961, p. 149.

${ }^{8}$ Tomalska 2013, p. 50.

${ }^{9}$ Efimov 1911, p. 49.

${ }^{10}$ Chernihiv eparchial tidings 1863 , p. 700

${ }^{11}$ Filaret 1874, p. 107; Katalog 1908, p. 158, 159.

${ }^{12}$ Filaret 1874, p. 66.
} 
belonging of the emblems speak alphabetic abbreviations on the shields ${ }^{1}$. Remarkable, that the Transfiguration church was builted by Danylo Apostol as the family mausoleum.

The Virgin Nativity cathedral in Hamaliya Kharlampiy monastery, Sumy region, also was conceived by hetman Ivan Skoropadsky as a proper family mausoleum. The monumental iconostasis (1735) of that church not preserved, but it also contained coats of arms of Skoropadsky' clan in the lower tier ${ }^{2}$.

Furthermore, it is a known, that the coat of arms of cossack colonel Pavlo Polubotok (in 17221724 he was the hetman) was in the lower tier of iconostasis in the church of Ascension, in Chernihiv ${ }^{3}$; the coat of arms of cossack colonel Fedir Ostrogradskyy was in the lower tier of iconostasis (1750) of the Dormition Church in village Hovtva (Poltava region) ${ }^{4}$; the coat of arms of cossack colonel Ivan Gamalia was in the iconostasis (1763) of church in village Borschiv (now is Bryansk region, Russia) ${ }^{5}$.

The high-ranking Orthodox priests giving money for a creation of iconostases, also follow to this practice. For example, two iconostases of the late $17^{\text {th }}$ century on the choir galleries in St. Nicholas (Military) Cathedral in Kiev contained in the lower tier the emblems of Iosaf Krokovsky, who was at that time the Archimandrite of Kyiv Pechersk Lavra ${ }^{6}$.

The placing of coats of arms in the lower tier of the iconostasis was fixed by tradition. They occupied places on the right and the left side from the Royal Doors or the emblem was placed below the icon of the saint patron or feast day to which the church was dedicated. The placing of the emblems beyond the lower tier of the iconostasis was rare. It is known the case mounting of emblem on the upper tier of the iconostasis (1663) in St. Nicholas (Military) Cathedral in Kiev. There the panel with coat of arms was part of the composition with an angel-painter, which stood on the cornice of the north wing of the iconostasis ${ }^{7}$. Another example of rare placing of emblem we can see on the silver Royal Doors of early $18^{\text {th }}$ century, created by expense of hetman Ivan Mazepa for the iconostasis of St. Boris and Gleb Cathedral in Chernihiv. There his coat of arms is situated on the column.

Apparently, the coats of arms in the iconostases of Right-bank Ukraine in the second half of $17^{\text {th }}$ - first half of $18^{\text {th }}$ centuries were not widespread, because such examples do not known. The reasons of this remain unclear. The single well-known example of using the emblems in the iconostasis of Right-bank Ukraine already refers to the last quarter of $18^{\text {th }}$ centuries. In the iconostasis (1784) of the Holy Spirit church in the village Huklyvyi, Zakarpattya region we can see the coat of arms of Austrian monarchy and the coat of arms of Bishop Andriy Bachynskyi, which are placed above the icons in the Sovereign tier to left and right of the Royal Doors. The character of location of these coats of arms, the introduction State Emblem side by side with the individual coat of arms as well as absence other examples and early tradition to introducing the coats of arms in the iconostasis in this region, forces to consider this case as a marginal, not associated with the practice that has developed in the Left-bank Ukraine. Furthermore, the coats of arms were added in iconostasis of the Holy Spirit church in that time, where this practice was ceased on the Left-bank Ukraine. For this reason, I do not take into account those emblems in the present research ${ }^{8}$.

The lower tier of iconostasis is not the best place for the coats of arms of donors, because the images in this tier could be hidden from the eyes behind a low barrier of solea, the portable lecterns or vases with flowers. But the emblems usually were placed there and it is definitely not a coincidence. Allow me to remind here that at that time, where the first emblems of donors were added in the iconostases, the coats of arms had already widespread in the altars of Polish-Lithuanian Commonwealth. Their placement in altars are vary significantly. The emblems could be on the entablature as in main altar of first half of the $16^{\text {th }}$ century in church of the Assumption of the Blessed Virgin Mary in Bodzentyn. The emblems could be on the sides of center image as in as in the main altar (about 1630) in the church

\footnotetext{
1 The letters 'ЄИВВЗФСДГДА' are found on the coats of arms of Danylo Apostol. It meaning following: 'Cя Императорского Величества Войска Запорожского Обеих Сторон Днепра Гетман Даніил Апостол’ [Hetman of Her Imperial Majesty and of the Zaporozhian Host on left and right bank of the Dnieper River, Danylo Apostol]. The letters 'СИВВЗПМПА' are found on the coats of arms of Pavlo Apostol. It meaning following: 'Ся Императорского Величества Войска Запорожского Полковник Миргородський Павел Апостол’ [Colonel of Her Imperial Majesty and city Myrhorod, Pavlo Apostol].

${ }^{2}$ Logvyn 1980, p. 216.

${ }^{3}$ Filaret 1874 , p. 71 .

${ }_{5}^{4}$ Arandarenko 1852 , p. 178.

${ }^{5}$ Lukomski, Modzalevski 1914, p. 31.

${ }^{6}$ Davydov 1910, p. 7.

${ }^{7}$ Davydov 1910.

8 M. Priymych recently suggested to interpretation those emblems as mapping of idea about parallelism of secular and spiritual power. For all details see: М. Приймич, Перед лицем твоїм. Закарпатський іконостас (In front of Thy Face. Iconostasis of Zakarpattia), Ужгород, 2007, pp. 130, 131.
} 
of St. Stanislav in village Piotrkowice, Świętokrzyskie Voivodeship. But is know much more examples where the emblems placed on the predella. In this case is used one emblem, as in the altar of 1612 in the Basilica of St. James and St. Agnes in Nysa or two different emblems as in the main altar of the church of the Holy Virgin Mary in Tuczno of early 1620 s years $^{1}$. Another possible manner to represent the coats of arms on predella we can see in the main altar of St. John the Baptist Church in town Volpa, Grodno region (Belarus). The altar was created in 1634 and on its predella there are two pairs of emblems and each pair of emblems is identical ${ }^{2}$. It is noteworthy that for the altars such scheme was one of many but for iconostasis became the general rule.

No doubt that the manner of emblems distribution on predella of altars served as the initial model for their location in the iconostasis. However, it does not assume that adoption of that model occurred by chance, because in the lower tier of iconostasis had locuses free from icons or a canon did not describe the iconography of this tier, and that allowed freely change the program of images in that tier, when the practice of marking of the emblems of donors the objects of donation achieved iconostasis. In the altars exist other options for placing for the emblems, but they not entrenched in the iconostasis. Therefore, the introduction of coat of arms just in the lower tier had particular significance.

Furthermore, the traditional hypothesis about vainglory of donor can not explain two important circumstances. First, in the lower tier of the iconostasis often placed several coats of arms that belonged to donor's clan. But for demonstration the fact of godly deed of donor is enough only his own emblem. Likewise donor acted, when decorated the church, built by him, or donated to church the liturgical subjects and books. Secondly, the introduction of two identical emblems of the one person in iconostasis is far beyond the tradition marking an object of donations of donor's emblems.

It allows considering the emblem of donor, as the part of iconographic program of the iconostasis and therefore the symbolic concept of iconostasis is the key for understanding of meaning of the coats of arms.

In the liturgical interpretation the main idea of iconostasis is described as clarification of the sacrament of the Eucharist ${ }^{4}$. At the same time, its iconographic structure is a systematized image of the whole Church of Christ where the icons are arranged according to the hierarchy of holiness ${ }^{5}$. If the complex of images in the iconostasis is united by common liturgical sense, it is logical to assume, that the meaning of donor's emblem is compatible with the overall concept of iconographic program. In turn, if the emblems were integrated to the symbolic program of the iconostasis as ones of sacred images, the meaning of the emblems must be changed or expanded, because the liturgical aspects of symbolism is not typical for a coats of arms. Therefore, the emblems in the iconostasis should lose meaning, inherent them in the space of secular culture. In other words, the meaning of the insignias in the iconostasis will be different from their meaning outside of its.

We have not the historical documents about the theological rationale for establishing of the coat of arms in the iconostasis. But the numerous examples of introduction the emblems in iconostasis, including belonging to the clergy, suggest that this practice had endorsement by the Church. The reason is a semantic role of emblems in the iconostasis.

According to the Christian tradition, an icon of saint possesses «similarity» which provides to icon the magical identity with the prototype ${ }^{6}$. That is why the icons in the iconostasis understand as the actual presence a multitude of saints. At the same time, the principles of historicism, which are characteristic for a Christian art and traditionally descriptive approach to reproduction of images of saints allows to called an icons as a portraits ${ }^{7}$.

Unlike icons, the coat of arms it is only a formalized symbol that functions as a legal and distinctive $\operatorname{sign}^{8}$. But this meaning of coat of arms is difficult to accept in the context of the iconostasis. Rather, in the system of iconic (portrait) images of the iconostasis, the coat of arms need to understand as a kind of code, that is associated to a person, but not only as distinctive sign or sign with legal meaning. It is the symbol, which points to a person and to functioning as his portrait. According to this interpretation, the significance of emblem is getting closer to the sense of portrait, because in essence the emblem is unique like a portrait. Although the emblem is not a facial image,

\footnotetext{
${ }^{1}$ Wujewski 2007, p. 129.

${ }^{2}$ Vysotska 1983, fig. 60.

${ }^{3}$ Zholtovski 1978, p. 92.

${ }^{4}$ Uspenski 1997, pp. 326, 327.

${ }^{5}$ Lidov 2014, pp. 356-401.

${ }^{6}$ Demus 1964, pp. 6, 7.

${ }^{7}$ Preobrazhenski 2012, p. 4.

${ }^{8}$ Arsen'ev 2001, p. 122.
} 
but it very accurately indicates to the person and describes his social status no less effective than the clothes and regalia.

The important argument for understanding of the emblem in the context of the iconostasis as a kind of «portrait» is the Byzantine concept of donor portraits in the interior of church. The image of donor not being a portrait. It was reproduction of image of human, which did not go beyond the common principles of Byzantine art ${ }^{1}$. However, the contemporaries recognized the person which was portrayed $^{2}$. The research of donor portraits of Medieval Rus' shows that religious art preserves the Byzantine concept of portrait until the $17^{\text {th }}$ century. Also, was widely spread the practice of replacing the image of donor on inscription, saint patron or scene where donor could see himself ${ }^{3}$.

Since in the medieval art in Rus' existed the model of perception the donor image not only through of his conditional-portrait, but other symbols or inscription, could suggest that in the $17^{\text {th }}$ century in this model was added the coat of arms - symbol which clearly relates to the person of donor. The introduction of emblem to the circle of symbolic images, that replaced portrait of donor is acceptable for Ukrainian society $17-18^{\text {th }}$ centuries, because at that time the coats of arms became very popular in cultural space of Ukraine.

Among the Orthodox of the Polish-Lithuanian Commonwealth understanding the coat of arms as the portrait of donor was prepared by wide use such visual scheme in the Catholic churches. The image of donor and his coat of arms often placed in the church, including on a sepulchral monument. Very common the donor and his family kneeling in prayer, in accompanied their coats of arms, are the part of the sacred image. Moreover, similar compositions can be placed on the border with the space of chapel in fact on the border with the sanctuary. In the iconostasis from that scheme was removed figure of donor and forsaken only his coat of arms.

If we agree that a coat of arms in iconostasis was symbolic «portrait» of donor, it is possible to explain the idea of the introduction of emblem in the iconographic program. Located in the iconostasis the coat of arms, like the portrait, had the «magical identity» with prototype, that is with human and in this sense it was similar to the iconic images. In this signification the emblem formally does not enter into conflict with other personal images in the iconostasis and could be included to the common symbolic space. At the same time, the coat of arms by virtue of its form of sign is unequal to icons. So, despite the emblem is placed in the iconostasis, it is expelled from the circle of images are intended for a worship.

The placing in the iconostasis of the emblem as a symbolic image of donor return us to the location of icons. Since the place of each image in the structure of the iconostasis submits to hierarchical organization, could assume that coats of arms situated in the lower tier according their importance. That is, occupy corresponding level. Of course, in terms of hierarchy, the topography of coats of arms in the iconostasis is quite logical: the lower tier is the least important in the system of tiers of iconostasis.

However, in whatever part of iconostasis the coats of arms be located, the symbolical images of donor and his family in any case will be among the congregation of saints. But according to the theological interpretation, unto all the fullness of holiness which shows the iconostasis, a human could join only after the judgement of $\mathrm{God}^{4}$. In this symbolic context the emblem could not be the «portrait» of living human. The emblem should be interpreted as a sign, forever belonging to man. It was his timeless symbol and in the iconostasis plays the role of a memorial portrait.

All this mean that function of the coat of arms in the iconostasis extend beyond a single goal indicate the person or family who made a pious contribution. In passing, can remember that images in the lower tier of iconostasis could be hidden from view by the lecterns, which traditionally put below the local icons of Christ and Virgin Mary. It is clear that the aim of glorification is not always performed. Then what was the aim for installation of emblems? Why donors sought to place them in the iconostasis?

Uncover this aim is possible if rely on the circle meanings inherent to the donor portraits in the Christian tradition. This issue is the subject of numerous researches. They speak, that the introduction the donor images in the iconographic program of the church primarily aimed to a prayerful appeal to God and the saints and gaining eternal life in reunion with God. The portraits of donors asked for prayer of parishioners and especially clergy of a church or monastery ${ }^{5}$ and such prayer is regularly offered. It is clear, that obligatory prayer for donors and benefactors during the church service explains the dissemination of the portraits of donors in the interiors Ukrainian churches $17-18^{\text {th }}$ centuries $^{6}$. In

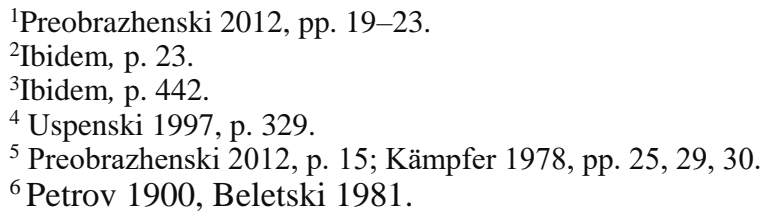


the Ukrainian churches in $17-19^{\text {th }}$ centuries the implementation of this rite is not abolished, even if for benefactor of the church had been declared anathema, as in the case of Hetman Ivan Mazepa ${ }^{1}$.

At that time the donor images in the church have got other aspects of meanings. In the Russian church tradition was a practice of placing the donor portraits near the relics or miraculous icons. The portraits replaced there the personal attendance of donor. The same meaning are getting the gifts of donors for different churches. They symbolized «imaginary pilgrimage» ${ }^{2}$. All this suggests that introduction of coat of arm to the iconostasis could be understand as a permanent presence of donor and his prayer to God.

Another fact helps better understand the aim of the emblem. In the Orthodox tradition in the lower tier of the iconostasis could be situated images related to the fate of the human soul after death. An example serves the tier of the Synodic icons of early 18th century, which was located in the lower tier of the iconostasis of the Peter and Paul church in Novgorod, Russia (now the icons are kept in the Novgorod museum) ${ }^{3}$. There are mentions about lighting candles for the dead near the lower tier of the iconostasis in the Serbian churches. ${ }^{4}$. It is considered, that the development of the theme of remembrance of the deceased at the lower tier of the iconostasis corresponds to the location of particles of prosphoron on the diskos on the Liturgy of Preparation ${ }^{5}$. Prayers for the dead there are in all rites of Divine Liturgy, beginning from ancient Liturgies ${ }^{6}$. It is clear that images in the lower tier of the iconostasis, when they relate to a particular person, should be seen by the memorial sense and the same meaning had the emblems of donor and his family.

In summary, note, that the iconostases which had the emblems of donors, didn't preserved (except iconostasis in the village Velyki Sorochyntsi). So, it is difficult to insist on any order of appearance the meaning of coats of arms in the iconostasis. Most probably that historically the initially purpose of the emblem of donor in the iconostasis really was fixing of the fact of contributions. But typologically, in the context of the iconostasis, another purpose becomes primary. The emblem - is the image of donor, who stands in prayer to God. Understanding of this new role of the coat of arms in the iconostasis led to introduction several of family coats of arms. The practice to introduce two emblem of one person in the iconostasis can be understand as a desire to enhance by doubling of symbols the effect of prayer request. This assumption explains to the logic of the customer, who places the emblem below the icons of Mother of God and of Christ. It is a prayer of donor personally to each of them.

For donor was not very important to his coat of arms was clearly visible to human. Therefore a lecterns that blocked view to the coat of arms were not changed anything. Most importantly, that God could see them. Of course, in that perception of emblem in the iconostasis is exceptions when vanity of donors prevailed. The example of this is the Royal Doors from the Borisoglebsky Cathedral in Chernihiv with the coat of arms of Hetman Ivan Mazepa. However, this does not mean that other his emblems in the iconostasis had only the purpose of glorifying.

\section{REFERENCES}

1. Arandarenko 1852: Н. Арандаренко, Записки о Полтавской губернии, составленные в 1816 г., vol. 3, Poltava 1852

2. Arsen'ev 2001: Ю. Арсеньев, Геральдика. Лекции, читанные в Московском Археологическом институте в 1907-1908 годах, Moscow 2001.

3. Beletski 1981: П. Белецкий, Украинская портретная живопись XVII-XVIII вв., Leningrad 1981.

4. Berlinski 1820: М. Берлинский, Краткое описание г. Києва, Saint Petersburg 1820.

5. Chernihiv eparchial tidings 1863: Chernihiv eparchial tidings, 24(1863), p. 700.

6. Chugreeva 2000: Н. Чугреева, 'Ряд икон синодиков и его литургическое значение в системе иконостаса', in: Иконостас. Происхождение - Развитие - Символика. Moscow 2000, pp 670-688.

7. Davydov 1910: Б. Давыдов, Никольский Военный собор в Киеве, Куіv 1910.

8. Demus 1964: O. Demus, Byzantine mosaic decoration. Aspects of monumental art in Byzantium, Boston 1964.

9. Efimov 1911: А. Ефимов, Свято-Троицкий-Ильинский монастирь, ныне Троицкий архиерейский дом, его прошлое и современное состояние: 1069-1911 г., Chernihiv 1911.

10. Filaret 1874: Филарет (Гумилевский), Историко-статистическое описание Черниговской епархии, vol. 5, Chernihiv 1874.

11. Florenski 1995: П. Флоренский, Иконостас, Moscow 1995.

\footnotetext{
${ }^{1}$ S.N.I. 1884 , p. $658-660$.

${ }^{2}$ Gnutova, Shchedrina 2006, p. 688, 689.

${ }^{3}$ Chugreeva 2000.

${ }^{4}$ Ibidem, p. 671.

${ }^{5}$ Uspensky 1992, p. 24.

${ }^{6}$ Golubtsov 1915, p. 594.
} 
12. Golubtsov 1915: А. Голубцов, 'Историческое объяснение обрядов литургии', Богословский вестник, vol. 2, 7/8(1915), pp. 563-601.

13. Gnutova, Shchedrina 2006: С. Гнутова, К. Щедрина, 'Кийский крест, Крестный монастырь и преображение сакрального пространства в эпоху патриарха Никона', Иеротопия. Создание сакральных пространств в Византии и Древней Руси, Moscow 2006, pp. 681-705.

14. Ikonostasis 2000: Иконостас. Происхождение - Развитие - Символика, ed. A. Lidov, Moscow 2000.

15. Kämpfer 1978: F. Kämpfer, Das russische Herrscherbild von den Anfangen bis zu Peter dem Grossen: Studien zur Entwicklung politischer Ikonographie im byzantinischen Kulturkreis, Recklinghausen 1978.

16. Karger 1961: М. Каргер, Древний Киев, vol. 2, Moscow-Leningrad 1961.

17. Katalog: Каталог выставки XIV археологического съезда в г.Чернигове, ed. P. Dobrovol'ski, Chernihiv 1908.

18. Lidov 2014: А. Лидов, Иконы. Мир святых образов в Византии и на Руси, Moscow 2014.

19. Logvyn 1980: Г. Логвин, Чернигов, Новгород-Северский, Глухов, Путивль, Moscow 1980.

20. Lukomski, Modzalevski 1914: В. Лукомский, В. Модзалевский, Малороссийский гербовник, Saint Petersburg 1914.

21. Modzalevski, Savitski 1992: В. Модзалевский, П. Савицкий, ‘Очерки искусства старой Украины’, in: Чернігівська старовина, Chernihiv 1992, pp. 101-142.

22. Nykytenko 2007: Н. Нікітенко, 'Головний іконостас Софії Київської як історико-культурний феномен', Пам’ятки України, 1(2007), pp. 22-46.

23. Pavlutski 1910: Г. Павлуцкий, 'Каменное церковное зодчество на Украине', in: История русского искусства, vol. 2, Moscow 1911, pp. 382-408.

24. Petrov 1900: Н. Петров, Об упразднении стенописи Великой церкви Киево-Печерской лавры, Куіv 1900.

25. Preobrazhenski 2012: А. Преображенский, Ктиторские портреты средневековой Руси. XI - начало XVI века, Moscow 2012.

26. S.N.I. 1884: С.Н.И., ‘Вопль Мазепы’, Киевская старина, vol. 10, 12(1884), pp. 658-672.

27. Stepovyk 1982: Д. Степовик, Українська графіка XVI-XVIII століть. Еволюція образної системи, Kyiv 1982.

28. Tomalska 2013: J. Tomalska, 'Supraśl Iconostasis. Problem of the Attribution', Series Byzantina. Studies on Byzantine and Post-Byzantine Art, XI(2013), pp. 41-56.

29. Uspensky 1992: Л. Успенский, Вопрос иконостаса, Moscow 1992.

30. Uspensky 1997: Л. Успенский, Богословие иконы Православной церкви, Pereslavl-Zalessky 1997.

31. Vysotskaya 1983: Н. Высоцкая, Пластыка Беларусі XII-XVIII стагоддзяў: альбом, Minsk 1983.

32. Wujewski 2007: T. Wujewski, 'Ołtarze w Tucznie i w Marcinkowicach a sprawa autorstwa Hermana Hana', Artium Quaestiones, XVIII (2007), pp. 117-149.

33. Zholtovski 1978: П. Жолтовський, Український живопис XVII-XVIII ст., Kyiv 1978.

34. Zholtovski 1983: П. Жолтовський, Художнє життя на Україні в XVI-XVIII ст., Kуіv 1983. 